\title{
PREFERENSI PETANI TERHADAP BUDIDAYA PADI SYSTEM OF RICE INTENSIFICATION (SRI) DI KELURAHAN DUSUN BESAR KECAMATAN SINGARAN PATI KOTA BENGKULU
}

\author{
Destrianah $^{1)}$, Bilman Wilman Simanihuruk ${ }^{2)}$, Satria Utama ${ }^{3)}$ \\ ${ }^{1)}$ Dinas Pertanian Provinsi Bengkulu \\ ${ }^{2)}$ Jurusan Agroekoteknologi Fakultas Pertanian \\ ${ }^{3)}$ Jurusan Agribisnis Fakultas Pertanian Universitas Bengkulu
}

\begin{abstract}
ABSTRAK
Pendekatan yang dapat dilakukan dalam upaya meningkatkan produktivitas padi sawah dan untuk menekan biaya produksi adalah melalui budidaya padi dengan System of Rice Intensification (SRI) yang merupakan suatu metode untuk meningkatkan produktivitas padi dengan mengubah pengaturan tanaman, tanah, air, dan nutrisinya. Pola pendekatan SRI adalah usaha tindakan yang bertujuan untuk memperoleh pertumbuhan tanaman optimal, kepastian panen, kualitas produksi dan kelestarian lingkungan. Penelitian ini bertujuan untuk mengetahui tingkat preferensi petani terhadap metode SRI dan menganalisis hubungan antara karakteristik internal dan eskternal petani dengan preferensi petani terhadap budidaya padi sawah dengan metode SRI. Yang dilaksanakan di Dusun Besar Kecamatan Singaran Pati Kota Bengkulu. Metode pengumpulan data dilakukan dengan wawancara dan observasi langsung ke lapangan. Metode analisis data dilakukan dengan analisis deskriptif, analisis rataan skor serta analisis korelasi. Tingkat preferensi petani terhadap metode budidaya SRI pada variabel keuntungan relatif dapat dikatakan suka dengan skor 3,89, tingkat kesesuaian dapat dikatakan tidak suka dengan skor 3,59, tingkat kerumitan dapat dikatakan suka dengan skor 3,91, tingkat kemudahan dilihat hasilnya dapat dikatakan suka dengan skor 3,78, tingkat kepuasan dapat dikatakan tidak suka dengan skor 3,30. Faktor pendapatan petani dan faktor frekuensi mengikuti latihan berpengaruh nyata terhadap tingkat preferensi budidaya SRI.
\end{abstract}

Kata Kunci: preferensi, budidaya, system of rice intensification,

\section{PENDAHULUAN}

Menurut Lewis (1989) teknologi pertanian adalah penerapan ilmu pengetahuan atau perangkat modern dalam melaksanakan pendayagunaan sumber daya alam serta sumber daya pertanian untuk meningkatkan kesejahteraan manusia. Menurut pakar ekologi, teknologi modern (pertanian yang tergantung pada bahan kimia) berdasarkan pertimbangan fisik dan ekonomi dianggap berhasil menanggulangi kerawanan pangan, namun harus dibayar mahal dengan makin meningkatnya kerusakan atau degradasi yang terjadi di permukaan bumi, seperti desertifikasi, kerusakan hutan, penurunan keanekaragaman hayati, salinitas, penurunan kesuburan tanah, pelonggokan (accumulation) senyawa kimia di dalam tanah maupun perairan, erosi dan kerusakan lainnya. Sampai saat ini masih merupakan dilema berkepanjangan antara usaha meningkatkan produksi pangan dengan menggunakan produk agrokimia dan usaha pelestarian lingkungan yang berusaha mengendalikan atau membatasi penggunaan bahan-bahan tersebut. Penggunaan pupuk kimia dan pestisida yang berlebihan dan tidak terkendali mempunyai dampak yang sama terhadap lingkungan (Sutanto, 2002). 
Salah satu cara pendekatan yang dapat dilaksanakan dalam upaya meningkatkan produktivitas padi sawah dan untuk menekan biaya produksi adalah melalui budidaya padi dengan System of Rice Intensification (SRI). System of Rice Intensification atau System Rancang Intensif adalah suatu metode untuk meningkatkan produktivitas padi dengan mengubah pengaturan tanaman, tanah, air, dan nutrisinya. Metode tersebut memberikan kontribusi terhadap kesehatan tanah, tanaman, dan memelihara mikroba tanah yang beranekaragam melalui bahan organik, tanpa pupuk kimia dan tanpa pestisida kimia, serta dapat menghemat penggunaan air hingga 50 persen (Fitriadi, 2005).

Masyarakat umum memerlukan waktu untuk dapat menerima teknologi baru. SRI adalah teknologi menuju pertanian organik. Teknologi ini bukan hal baru bagi petani di Kecamatan Singaran Pati namun belum semua petani menerapkan metode tersebut. Petani memerlukan waktu dalam mengadopsi metode SRI dan setiap masyarakat mempunyai tingkat preferensi yang berbeda-beda. Petani pada umumnya takut menanggung resiko terutama penurunan produksi karena menggunakan teknologi baru. Menurut Harjoso et al, (2011) melalui teknologi yang digunakan pada budidaya padi organik metode SRI diperoleh beberapa keuntungan baik dari hasil maupun sarana produksi yang lebih hemat. Selain hal tersebut, dengan menggunakan metode SRI tidak akan merusak lingkungan, bersifat ramah lingkungan, dapat menghemat biaya produksi karena dalam penerapan metode SRI ini menggunakan pupuk organik. Penggunaan pupuk organik dapat memperbaiki sifat fisik dan kimiawi tanah, struktur tanah, daya meresap air serta daya mengikat air oleh tanah.

Salah satu kecamatan yang memiliki luasan cukup luas dalam hal penerapan metode SRI dan lokasi yang pertama mendapatkan bimbingan intensif dalam men- erapkan SRI adalah Kecamatan Singaran Pati. Kelurahan di Kecamatan Singaran Pati yang telah dikenalkan dan dibimbing secara intensif dalam menerapkan SRI adalah $\mathrm{Ke}$ lurahan Dusun Besar sehingga kelurahan tersebut dipilih sebagai lokasi penelitian. Kelurahan Dusun Besar terdapat empat kelompok tani yang telah dibimbing secara intensif dalam menerapkan SRI, namun demikian belum semua anggota kelompok tani menerapkan teknologi tersebut. Ada yang sampai saat ini terus menerapkan SRI, dan ada yang kembali ke konvensional. Oleh karena itu perlu dilakukan penelitian tentang tingkat preferensi petani terhadap teknik budidaya padi dengan metode SRI. Tujuan dilaksanakannya penelitian ini adalah untuk mengetahui tingkat preferensi petani terhadap metode SRI dan menganalisis hubungan antara karakteristik internal dan eskternal petani dengan preferensi petani terhadap budidaya padi sawah dengan metode SRI.

\section{METODE PENELITIAN}

\section{Waktu dan Tempat Penelitian}

Penelitian ini dilaksanakan bulan Oktober 2018 di Kelurahan Dusun Besar Kecamatan Singaran Pati Kota Bengkulu.

\section{Metode Pengambilan Sampel}

Petani yang dijadikan sampel adalah anggota kelompok tani yang melaksanakan SRI dan yang kembali ke metode konvensional. Kelurahan Dusun Besar terdapat empat kelompok tani yaitu kelompok Tani Talang Ilo, Kelompok Tani Sekotong, Kelompok Tani Lembak AO II, dan Kelompok Tani Batang Hari. Keempat kelompok tani ini pernah mendapatkan bimbingan intensif dari Dinas Pertanian dalam menerapkan metode SRI. Masingmasing kelompok tani beranggotakan 20 orang sehingga populasi sebanyak 80 orang.

Populasi petani yang melakukan budidaya padi dengan metode SRI 
sebanyak 19, dan anggota yang kembali ke metode konvensional sebanyak 61. Pengambilan sampel petani menggunakan rumus (Rakhmat,1995).

Jadi sampel petani yang menerapkan SRI adalah 16 orang. Jumlah sampel petani yang pernah menerapkan SRI dan kembali ke metode konvensional. Sampel petani yang pernah menerapkan SRI tetapi kembali ke konvensional adalah 38 orang. Jadi total sampel penelitian adalah 54 orang.

\section{Metode Analisis}

Analisis korelasi, faktor-faktor yang mempengaruhhi preferensi petani dianalisis kuantitatif dari data hasil survey dengan menggunakan program SPSS 18. Analisis kuantitatif untuk mengetahui hubungan antara variabel tak bebas (Y) yaitu preferensi petani terhadap budidaya padi SRI dan lima variabel bebas $(\mathrm{X})$ yang merupakan data karakteristik responden. Data karakteristik terdiri atas umur $\left(\mathrm{X}_{1}\right)$, tingkat pendidikan $\left(\mathrm{X}_{2}\right)$, luas penguasaan lahan $\left(\mathrm{X}_{3}\right)$, tingkat pendapatan $\left(\mathrm{X}_{4}\right)$ dan frekuensi mengikuti latihan $\left(\mathrm{X}_{5}\right)$. Variabel tak bebas (Y) adalah preferensi petani terhadap SRI merupakan skala nominal. Untuk itu peneliti menggunakan model regresi logit biner (Gujarati, 1999) untuk mengetahui hubungan antara variabel bebas dan variabel tak bebas. Hosmer et al., (2000) mengatakan bahwa regresi logistik adalah suatu metode analisis statistika untuk mendeskripsikan hubungan antara variabel terikat yang memiliki dua kategori atau lebih dengan satu atau lebih peubah bebas berskala kategori atau kontinu. Uji model dilakukan HASIL DAN PEMBAHASAN

Preferensi Petani Terhadap Budidaya SRI untuk memeriksa peranan variabel prediktor terhadap variabel respon secara serentak atau secara keseluruhan (Tampil et al., 2017). Model yang digunakan adalah sebagai berikut:

$$
\mathrm{Yi}=\mathrm{b}_{0}+\mathrm{b}_{\mathrm{i}} \mathrm{X}_{\mathrm{i}}+\mathrm{e}_{\mathrm{i}}
$$

Variabel bebas sesuai model sebanyak 5 variabel sehingga persamaan (1) di atas dijabarkan sebagai berikut:

$Y_{i}=b_{0}+b_{1} X_{1}+b_{2} X_{2}+b_{3} X_{3}+b_{4} X_{4}+b_{5} X_{5}+e$

keterangan:

$\mathrm{Y}_{\mathrm{i}}=$ Preferensi

$\mathrm{X}_{1}=$ Umur responden (tahun)

$\mathrm{X}_{2}=$ Tingkat pendidikan (tahun)

$\mathrm{X}_{3}=$ Luas penguasaan lahan (hektar)

$\mathrm{X}_{4}=$ Pendapatan usaha tani padi $(\mathrm{Rp} / \mathrm{MT})$

$\mathrm{X} 5=$ Frekuensi mengikuti latihan (kali)

$\mathrm{e}_{\mathrm{i}}=$ Error

$\mathrm{b}_{0}=$ Konstanta

$\mathrm{b}_{1 \ldots .} \mathrm{b}_{5}=$ Parameter dugaan (koefisien)

Model tersebut linier, maka dilakukan transformasi dengan logaritma natural (ln) sehingga menjadi:

$$
\begin{aligned}
\mathrm{Yi}=\ln \frac{P(X i)}{1-P(X i)} & \\
& =\mathrm{b} 0+\mathrm{b} 1 \mathrm{X} 1+\mathrm{b} 2 \mathrm{X} 2+\mathrm{b} 3 \mathrm{X} 3 \\
& +\mathrm{b} 4 \mathrm{X} 4+\mathrm{b} 5 \mathrm{X} 5
\end{aligned}
$$

Dalam penelitian ini, data diolah menggunakan perangkat lunak SPSS (Statistic Program for Social Science) 18.

Preferensi petani terhadap budidaya SRI disajikan dalam Tabel 1. 
Tabel 1.Skor komponen preferensi petani terhadap budidaya SRI

\begin{tabular}{cllll}
\hline No & Variabel & Rata-rata & Kisaran & Kategori \\
\hline 1 & Keuntungan relative & 19.46 & $16-24$ & $3.89 /$ suka \\
2 & Tingkat kesesuaian & 17.98 & $14-23$ & $3.59 /$ tidak suka \\
3 & Tingkat kerumitan & 19.59 & $17-22$ & $3.91 /$ suka \\
4 & Tingkat kemudahan dilihat hasilnya & 18.94 & $15-24$ & $3.78 /$ tidak suka \\
5 & Tingkat kepuasan & 29.74 & $23-40$ & $3.30 /$ tidak suka \\
\hline
\end{tabular}

Berdasarkan Tabel 1 dapat dilihat bahwa ada 2 kategori preferensi petani terhadap budidaya SRI yaitu suka dan tidak suka, dari hasil data penelitian yang telah diolah didapatkan range nilai kategori adalah 3,30-3,91. Jadi dengan ini penulis menentukan suka atau tidak suka dari nilai tengah kategori tersebut. Dikatakan suka jika nilai kategori variabel $>3,605$ dan tidak suka jika nilai kategori variabel $<3,605$.

Pada skor rata-rata petani rata-rata setuju/suka bahwa budidaya SRI mendapat keuntungan secara ekonomis, cukup rumit di dalam pelaksanaan dan mudah dalam melihat hasilnya. Dari wawancara yang telah dilakukan terhadap petani hanya sebagian kecil saja yang menyukai sistem budidaya SRI, petani tidak mau mengambil risiko kegagalan yang dapat merugikan petani, dan petani belum sepenuhnya menerima manfaat dari adanya program SRI, sehingga petani menganggap bahwa program SRI belum sepenuhnya tercapai, hal inilah yang menyebabkan petani kembali ke metode konvensional. Padahal pertama kali budidaya ini dikenalkan masing-masing petani mempunyai preferensi yang hampir sama terhadap usahatani padi yang mereka lakukan tetapi lama-kelamaan karena tidak sesuai dengan yang diharapakan petani banyak yang kembali ke metode yang lama.

Tabel 1 menunjukkan bahwa keuntungan relatif yang di dapat dari pengembangan budidaya SRI dapat dirasakan oleh masyarakat, pada penilaian rata-rata responden tehadap SRI berkisar pada 16-24 dengan rata-rata 19,46 . Hal ini terlihat dari manfaat ekonomis dimana petani dapat menghemat biaya selama proses budidaya berlangsung, manfaat teknis dengan menghemat waktu yang ada, adanya kenaikan pendapatan yang diperoleh dari suatu asumsi atau pendapat. Seharusnya suatu budidaya baru/teknologi baru cepat untuk diterima dan dikuasai oleh masyarakat. Penelitian Utomo (2012) menyatakan bahwa manfaat ekonomis inovasi menggunakan metode SRI dianggap mempunyai manfaat yang lebih baik dan biaya lebih murah dibanding dengan menggunakan metode konvensional.

Tingkat kesesuaian pengembangan budidaya SRI yang terdapat pada Tabel 1 . adalah dengan kisaran 14-23 dengan rata-rata 17,98, dapat dilihat dari nilai tersebut bahwa sikap responden adalah biasa dan kurang setuju dengan adanya budidaya SRI ini. Tingkat kerumitan dengan kisaran 17-22 dan rata-rata 19,59. Hal ini telah tergolong rumit dimana dalam hal pengairan dan pemupukan. Nugraheni (2014) menyatakan pengairan lebih rumit karena harus ada penggenangan dan pengeringan lahan pada umur-umur tertentu. Pemupukan lebih rumit karena petani harus membuat bahan organik dan pestisida organik sendiri. Kerumitan berikutnya adalah dalam pengangkutan pupuk kandang ke lokasi atau sawah yang letaknya jauh dari jalan.

Tingkat kemudahan dilihat dari hasilnya dengan kisaran 15-24 dan rata-rata 18,94, hal ini menyatakan bahwa sebagian besar masyarakat setuju dengan kemudahan yang di dapatkan dari budidaya SRI (dimana gabah lebih baik/lebih mentes). Hal ini sesuai dengan Rogers (1983) dalam Alisa (2007) yang mengemukakan bahwa tingkat kemudahan 
suatu teknologi/inovasi untuk dilihat hasilnya adalah derajat dimana hasil inovasi itu dapat dilihat atau dirasakan oleh penganut yang berpotensi (potential adopter). Untuk tingkat kepuasaan petani terhadap SRI dengan kisaran 23-40 dan rata-rata 29,7. Untuk skor penilaian tingkat kepuasaan menggunakan 9 pertanyaan makanya mendapat total skor yang cukup jauh berbeda dengan yang variabel lainnya. Berdasarkan hasil tersebut dapat diperkirakan bahwa budidaya SRI tidak terlalu meningkatkan kepuasan petani, seperti yang dikatakan Gani et al., (2002) dalam Handono (2013) di dalam menerapkan SRI ada beberapa kesulitan yang dihadapi oleh petani antara lain 1) pengelolaan irigasi dan pengendalian air yang berkala, hal ini tidak mudah untuk diterapkan oleh petani yang mengakibatkan aerasi tanah meningkat dan petani tidak menyadarinya 2) kebutuhan tenaga kerja lebih tinggi dibandingkan dengan praktek tradisi nasional 3) banyak kendala dalam menanam bibit muda dan per lubang dengan satu tanaman 4) beberapa hama dan penyakit menyerang bibit muda setelah tanam. Sehingga untuk menerapkan SRI sangat sulit, namun hal tersebut dapat diterapkan secara intensif jika petani sudah yakin dan sudah mendapatkan keterampilan dalam metode ini.

\section{Faktor yang Mempengaruhi Preferensi Budidaya SRI}

Faktor-faktor yang mempengaruhi preferensi budidaya SRI usahatani padi sawah pada penelitian ini digunakan fungsi regresi logistic. Hasil estimasi dari fungsi tersebut dapat dilihat pada Tabel 2 .

Tabel 2. Hasil estimasi faktor yang mempengaruhi preferensi budidaya SRI

\begin{tabular}{clccc}
\hline No & \multicolumn{1}{c}{ Variabel bebas } & Koefisien & p-value & Odds Ratio \\
\hline 1 & X1 (Umur) & $-1,507$ & 0,800 & 0,222 \\
2 & X2 (Pendidikan) & $-0,270$ & 0,807 & 0,763 \\
3 & X3 (Luas lahan) & $-1,136$ & 0,372 & 0,321 \\
4 & X4 (Pendapatan) & 2,897 & 0,042 & 18,126 \\
5 & X5 (Frekuensi mengikuti pelatihan) & 2,381 & 0,003 & 10,812 \\
\hline & Konstanta & $-0,079$ & & \\
\hline
\end{tabular}

Pada pengujian variabel mana saja yang berpengaruh nyata terhadap preferensi digunakan uji signifikasi dari parameter koefisien secara parsial dengan statistic uji Chi-Squares. Dari output SPSS 18 (Lampiran 6) Nilai Nagelkerke $\mathrm{R}^{2}$ (koefisien determinasi) yang diperoleh pada usahatani padi sawah sistem tanam SRI sebesar 0,473

$$
\mathrm{Yi}=\ln \frac{P(X i)}{1-P(X i)}=-0,079-1,507 \mathrm{X} 1-0,270 \mathrm{X} 2-1,136 \mathrm{X} 3+2,897 \mathrm{X} 4+2,381 \mathrm{X} 5
$$

$(47,3 \%)$. Persamaan ini hanya bisa menjelaskannya sebesar $47,3 \%$ dari variasi atau sebaran data serta tingkat keterwakilannya masih rendah. Persamaaan model regresi logit biner preferensi petani terhadap budidaya SRI dapat ditulis sebagai berikut: 
$\mathrm{P}(\mathrm{Xi})$ adalah preferensi petani terhadap budidaya SRI, sebagai kebalikan dari 1-P(Xi) sebagai preferensi petani yang tidak sesuai terhadap budidaya SRI. Jika nilai konstanta tidak dimasukkan, maka persentasi kecocokan preferensi budidaya SRI adalah 51,9\%.
Berdasarkan tabel di bawah dapat dijelaskan bahwa petani dari yang tidak suka menjadi suka sebanyak 26 orang dan petani yang suka menjadi suka sebanyak 28 orang (Tabel 3 dan Tabel 4).

Tabel 3. Persentasi kecocokan preferensi petani terhadap budidaya SRI

\begin{tabular}{lccc}
\hline Preferensi & Tidak suka & Suka & Kecocokan $(\%)$ \\
\hline Tidak suka & 0 & 26 & 0 \\
Suka & 0 & 28 & 100 \\
\hline & & & 51,9 \\
\hline
\end{tabular}

Tabel 4. Klasifikasi preferensi petani terhadap budidaya SRI

\begin{tabular}{lccc}
\hline \multicolumn{1}{c}{ Preferensi } & Tidak suka & Suka & Kecocokan $(\%)$ \\
\hline Tidak suka & 20 & 6 & 76,9 \\
Suka & 6 & 22 & 78,6 \\
\hline
\end{tabular}

Berdasarkan tabel tersebut dapat dijelaskan bahwa ada 12 orang yang salah klasifikasi, petani yang suka menjadi tidak suka sebanyak 6 orang, petani yang tidak suka menjadi tidak suka sebanyak 20 orang, petani yang tidak suka menjadi suka sebanyak 6 orang, petani yang suka menjadi suka sebanyak 22 orang.

\section{Umur}

Semakin muda petani biasanya mempunyai semangat untuk ingin tahu apa yang belum diketahui, sehingga dengan demikian mereka berusaha untuk lebih cepat untuk menyukai/menerapkan suatu inovasi walaupun sebenarnya mereka masih belum berpengalaman terhadap inovasi tersebut. Hasil analisis regresi logistik pada Tabel 2. menunjukkan bahwa faktor umur berpengaruh tidak nyata terhadap peluang preferensi budidaya SRI. Faktor umur berpengaruh tidak nyata terhadap preferensi dimana nilai variabel bebas umur sebesar 0,8 > 0,1 (10\% / nilai alpha yang telah ditentukan).
Berdasarkan hal ini penerapkan budidaya SRI tidak berdasarkan tingkatan umur, petani sama-sama berpeluang dalam menyukai atau tidaknya budidaya SRI. Selain itu, usahatani yang dilakukan berjalan secara turun menurun dan dipengaruhi oleh kemampuan petani sendiri serta situasi dan kondisi masyarakat petani sekitar. Hal ini sejalan dengan penelitian Suwarni (2003) yang menyatakan bahwa umur tidak berhubungan nyata dengan tingkat adopsi teknologi usahatani padi pada lahan pasang surut serta dalam penelitian Astuti (2014), menunjukkan bahwa umur tidak memiliki hubungan yang nyata dengan tingkat preferensi petani dalam usahatani padi karena umur tidak menjamin dalam penumbuhan tingkat preferensi. Umur hanya mempengaruhi pengalaman tetapi pengalaman penanaman padi tidak mempengaruhi preferensi petani. Hal ini menunjukkan bahwa baik petani yang memiliki umur produktif maupun tidak, mereka akan memiliki preferensi berusahatani padi. 


\section{Pendidikan}

Hasil analisis regresi logistik pada Tabel 2. menunjukkan bahwa faktor tingkat pendidikan berpengaruh tidak nyata terhadap peluang preferensi budidaya SRI, dimana nilai variabel pendidikan 0,807 > 0,1 . Ada beberapa kemungkinan yang menyebabkan terjadinya berpengaruh tidak nyata antara tingkat pendidikan dan preferensi budidaya SRI. Penyebab tersebut antara lain adalah untuk menerapkan suatu teknologi dalam usahataninya, petani tidak harus memiliki tingkat pendidikan formal yang tinggi, petani sama-sama berpeluang dalam menyukai budidaya SRI. Hal yang sama juga terdapat dalam hasil penelitian Kusmiati (2009) yang menyatakan bahwa tingkat pendidikan formal tidak berhubungan nyata dengan tingkat adopsi teknologi kimia-biologis pada usahatani padi sawah. Serta dalam Widiyastuti et al. (2016) mengatakan bahwa hubungan antara pendidikan formal dengan preferensi petani terhadap pengembangan SRI di Kecamatan Moga Kabupaten Pemalang tidak signifikan. Hubungan yang tidak signifikan menunjukkan bahwa tinggi rendahnya pendidikan formal responden tidak berhubungan nyata dengan preferensi petani terhadap pengembangan SRI. Pengetahuan dan informasi yang diperoleh responden tentang SRI didapatkan melalui kegiatan yang bukan berasal dari hasil pendidikan formal.

\section{Luas lahan}

Luas lahan adalah besarnya lahan yang dianggap oleh petani untuk kegiatan usahataninya. Hasil regresi logistik pada Tabel 2. menunjukkan bahwa faktor luas penguasaan lahan tidak berpengaruh nyata terhadap tingkat preferensi budadaya SRI. Dimana nilai variabel bebas penguasaan lahan 0,372>0,1. Lionberger dalam Mardikanto (1996) menyebutkan bahwa semakin luas penguasaan lahan biasanya semakin cepat mengadopsi, karena memiliki kemampuan ekonomi yang lebih baik. Pernyataan tersebut tidaklah sesuai dengan hasil penelitian yang diperoleh. Petani yang memiliki lahan yang luas sama-sama berpeluang dalam menerapkan budidaya SRI dengan petani yang lahannya sempit atau sebaliknya. Hal yang sama juga dikatakan oleh Widiyastuti et al. (2016) yang diperoleh dari hasil penelitiannya yang mengatakan bahwa hubungan antara luas lahan dengan preferensi petani terhadap pengembangan SRI di Kecamatan Moga Kabupaten Pemalang tidak signifikan. Hal ini menunjukkan bahwa luas sempitnya suatu lahan tidak berhubungan nyata dengan preferensi petani terhadap pengembangan SRI. Lahan sawah yang luas ataupun sempit tidak berpengaruh terhadap cara yang dilakukan petani dalam berusahatani padi. Petani dalam melakukan usahatani tidak melihat seberapa luas lahan yang dimiliki melainkan risiko apa yang akan terjadi apabila menggunakan suatu teknologi baru yang sebelumnya belum pernah dilakukannya ataupun sudah dilakukan namun masih mengalami kegagalan dalam berusahatani.

Ada beberapa kemungkinan yang menyebabkan faktor luas penguasaan lahan berpengaruh tidak nyata terhadap preferensi budidaya SRI antara lain adalah bahwa penerapan SRI dapat dilakukan oleh petani yang memiliki lahan sempit, sedang mapun luas. Hal tersebut sejalan denga penerapan budidaya SRI, dimana penerapan SRI dapat dicobakan pada lahan sempit, sedang dan luas. Hasil penelitian ini sesuai dengan Junaria (2007) yang menjelaskan bahwa petani dengan lahan yang luas belum tentu tingkat penerapannya tinggi dan yang terjadi adalah sebaliknya, petani masih merasa takut jika terjadi kegagalan.

\section{Pendapatan petani}

Hasil analisis regresi logistic pada Tabel 2. menunjukkan bahwa faktor pendapatan petani berpengaruh nyata terhadap budidaya SRI, dengan nilai variabel bebas pendapatan $0,042<0,1$. Soekartawi (1988), menyatakan bahwa petani yang berpendapatan tinggi akan bertindak dan berprilaku lebih dinamis dan lebih mudah melakukan inovasi dalam pembangunan, sedangkan petani yang berpendapatan rendah akan lebih lambat dalam melakukan inovasi. 
Berdasarkan pendapat tersebut dapat diasumsikan rata-rata responden memiliki pendapatan sedang dan tinggi sehingga responden akan bertindak dan berprilaku lebih dinamis dan mudah melakukan inovasi baru.

\section{Frekuensi Mengikuti Pelatihan}

Hasil analisis regresi logistic pada Tabel 2. menunjukkan bahwa faktor frekuensi dalam mengikuti pelatihan yang diikuti oleh petani berpengaruh nyata terhadap budidaya SRI, dengan nilai variabel bebas frekuensi mengikuti pelatihan 0,003 < 0,1 . Berdasarkan hasil wawancara yang telah dilakukan maka petani yang masih tetap menerapkan SRI adalah rata-rata ketua kelompok tani. Dimana mereka lebih banyak dan lebih sering mengikuti pelatihan pertanian dibandingkan petani yang kembali ke metode konvensional. Hal yang mendukung dengan hasil penelitian ini adalah seperti dalam Widiyastuti et al., (2016) yang menyatakan bahwa frekuensi mengikuti latihan dalam kategori sedang atau atau cukup berpengaruh dengan presentase $61 \%$. Hal ini merupakan salah satu faktor yang dapat mempengaruhi petani untuk bisa menerima inovasi baru atau informasi baru yang mampu menambah pengetahuan dan wawasan petani tentang usahataninya. Frekuensi mengikuti latihan mampu membentuk petani untuk menjadi petani yang lebih maju sehingga petani dapat meningkatkan produktivitas usahataninya. Frekuensi mengikuti latihan juga berpengaruh terhadap keputusan yang akan diambil oleh petani.

\section{KESIMPULAN}

Tingkat preferensi petani terhadap metode budidaya SRI pada variabel keuntungan relatif dengan skor rata-rata 3,89 dapat dikategorikan suka, tingkat kesesuaian dengan skor rata-rata 3,59 dapat dikategorikan tidak suka, tingkat kerumitan dengan skor rata-rata 3,91 dapat dikategorikan suka, tingkat kemudahan dilihat hasilnya dengan skor rata-rata 3,78 dapat dikategorikan suka, tingkat kepuasan dengan skor rata-rata 3,30 dapat dikategorikan tidak suka.

Faktor internal yang berupa pendapatan petani dan faktor eksternal yang berupa frekuensi mengikuti latihan berpengaruh nyata terhadap tingkat preferensi budidaya SRI.

\section{DAFTAR PUSTAKA}

Alisa, I. 2007. Persepsi petani terhadap inovasi untuk menggunakan pupuk kompos kotoran ternak produk $\mathrm{P}_{4} \mathrm{~S}$ Bumi Lestari Sragen (Kasus Petani di Desa Gondang Kecamatan Gondang Kabupaten Sragen). Skripsi. Program Studi Sosial Ekonomi Peternakan. Fakultas Peternakan. Institut Pertanian Bogor.

Astuti, R.P. 2014. Motivasi Petani dalam Usahatani Padi Organik di Kecamatan Pandak Kabupaten Bantul. Laporan Penelitian Sarjana Program Studi Agribisnis. Fakultas Pertanian. Universitas Muhammadiah Yogyakarta.

Fitriadi, F. 2005. Analisis pendapatan dan marjin pemasaran padi ramah lingkungan (Kasus Di Desa Sukagalih Kecamatan Sukaratu Kabupaten Tasikmalaya). Skripsi. Departemen Ilmu-Ilmu Sosial Ekonomi Pertanian. Fakultas Pertanian. Institut Pertanian Bogor. Bogor.

Gujarati, D. 1999. Ekonometrika Dasar. Alih Bahasa Sumarno Zain. Erlangga. Jakarta.

Handono, S.Y. 2013. Hambatan dan Tantangan Penerapan Padi Metode SRI (System of Rice Intensification). Jurusan Sosial Ekonomi. Fakultas Pertanian. Universitas Brawijaya. Habitat 24 (1): 10-19.

Harjoso T., N. Siti, Y.R. Ahadiyat. 2011. Karakter Morfologi Padi pada Pertanaman dengan Pendekatan 
SRI (System of Rice Intensification). Agrin. 15 (2).

Hosmer, D.W., dan S. Lemeshow. 2000. Applied Logistic Regression. Edisi ke-2. John Wiley and Sons Inc. Canada.

Junaria, R. 2007. Faktor-Faktor yang Berhubungan dengan Tingkat Adopsi Petani pada Teknologi Budidaya Padi Sawah Sistem Legowo di Kelurahan Dusun Besar Kecamatan Gading Cempaka Kota Bengkulu. Skripsi (S1) Jurusan Sosial Ekonomi Fakultas Pertanian. Universitas Bengkulu. Bengkulu. (Tidak Dipublikasikan)

Kusmiati. 2009. Faktor-Faktor yang Mempengaruhi Adopsi Teknologi Kimia-Biologis Usahatani Padi Sawah di Kota Bengkulu. Skripsi (S1) Jurusan Sosial Ekonomi Fakultas Pertanian. Universitas Bengkulu. Bengkulu. (Tidak Dipublikasikan)

Lewis, H.L. 1989. Teknologi Canggih dan Kebebasan Manusia. Yayasan Obor Indonesia. Jakatra.

Mardikanto, T. 1988. Komunikasi Pembangunan. UNS Press. Surabaya.

Rakhmat, J. 2004. Psikologi Komunikasi. Rosdakarya Group. Bandung.

Soekartawi. 1988. Prinsip Dasar Koтиnikasi Pertanian. Universitas Indonesia. Jakarta.

Sutanto, R. 2002. Pertanian Organik: Menuju Pertanian Alternatif dan Berkelanjutan. Kanisius. Yogyakarta.
Suwarni, A. 2003. Analisa Faktor-Faktor Sosial Ekonomi yang Berhubungan dengan Tingkat Adopsi Teknologi Usahatani Pasang Surut dan Sumbangan Usahatani terhadap Total Penerimaan Petani. Skripsi (S1) Jurusan Sosial Ekonomi Fakultas Pertanian. Universitas Bengkulu. Bengkulu. (Tidak Dipublikasikan) Tampil Y.A., H. Komalig, Y. Langi. 2017. Analisis Regresi Logistik Untuk Menentukan Faktor-Faktor Yang Mempengaruhi Indeks Prestasi Kumulatif (IPK) Mahasiswa FMIPA Universitas Sam Ratulangi Manado. Program Studi Matematika, Fakultas Matematika dan Ilmu Pengetahuan Alam. Universitas Sam Ratulangi Manado. JdC. 6 (2).

Utomo, P. 2012. Persepsi Petani terhadap Metode Budidaya Padi System of Rice Intensification (SRI) di Desa Ringgit Kecamatan Ngombol Kabupaten Purwokerto. Program Studi Agribisnis. Fakultas Pertanian. Universitas Muhammadiyah Purwokerto.

Widiyastuti, E. Widiyanti, Sutarto. 2016. Persepsi Petani Terhadap Pengembangan System of Rice Intensification (SRI) di Kecamatan Moga Kabupaten Pemalang. Program Studi Agribisnis Fakultas Pertanian. Universitas Sebelas Maret Surakarta. Agrista 4 (3) : 476-485. 